\title{
PENERAPAN MODEL PEMEBELAJARAN GRUP IVESTIGATION UNTUK MENINGKATKAN AKTIVITAS DAN HASIL BELAJAR IPS SISWA KELAS VII SMPN 1 SENORI TAHU PELAJARA 2019/2020
}

\author{
Sri Susi Wiji Astuti ${ }^{1}$,Sarjono ${ }^{2}$, Ahmad Hariyadi ${ }^{3}$ \\ Prodi Pendidikan Ekonomi, Fakultas Pendidikan dan Ilmu Pengetahuan Sosial ${ }^{1}$ \\ Prodi Pendidikan Kewarganegaraan Fakultas Pendidikan dan Ilmu Pengetahuan Sosial ${ }^{2}$ \\ ${ }^{1}$ Corresponding Email: srisusiwijiastuti@gmail.com ${ }^{1}$, Phone Number : 082213556395
}

Received: 02 Oktober 2020; Revised: 21 November 2020; Accepted: 28 Desember 2020 DOI: http://dx.doi.org/10.37905/aksara.7.1.37-42.2021

\begin{abstract}
Activities and student learning outcomes by applying a group investigation learning model. This research was conducted at SMPN 1 Senori. The subjects of this study were class VII students in the 2019/2020 school year. The results of this study obtained data that teacher activity has increased namely in the first cycle $45.45 \%$, the second cycle $70.45 \%$, and the third cycle $81.81 \%$. Student activity has increased namely in the first scilus by $44.93 \%$, cycle II by $52.07 \%$, and cycle III by $68.31 \%$ and student learning outcomes also increased by $62.83 \%$ and $72.90 \%$ for the first scilus , the second cycle was $71.22 \%$ and $75.96 \%$, the third cycle was $72 \%$ and $78.06 \%$. Based on the results of this study, it can be concluded that the application of the Group Investigation learning model can increase the activities and social learning outcomes of VII students grade of SMPN 1 Senori in the 2019/2020 school year.
\end{abstract}

\begin{abstract}
Abstrak
Aktivitas dan hasil belajar siswa dengan menerapkan model pembelajaran group investigation. Penelitian ini dilaksanakan di SMPN 1 Senori. Subyek penelitian ini adalah siswa kelas VII tahun pelajaran 2019/2020. Hasil penelitian ini diperoleh data bahwa Aktivitas guru mengalami peningkatan yaitu pada siklus I sebesar $45,45 \%$, siklus II sebesar 70,45\%, dan siklus III sebesar $81,81 \%$. Aktivitas siswa mengalami peningkatan yaitu pada skilus I sebesar 44,93\%, siklus II sebesar 52,07\%, dan siklus III sebesar $68,31 \%$ dan Hasil belajar siswa juga mengalami peningkatan yaitu pada skilus I sebesar $62,83 \%$ dan $72,90 \%$, siklus II sebesar $71,22 \%$ dan $75,96 \%$, siklus III sebesar $72 \%$ dan $78,06 \%$. Berdasarkan hasil penelitian tersebut, dapat disimpulkan bahwa penerapan model pembelajaran Group Investigation dapat meningkatkan aktivitas dan hasil belajar IPS siswa kelas VII SMPN 1 Senori tahun ajaran 2019/2020.
\end{abstract}

\section{Pendahuluan}

Pendidikan merupakan suatu proses menjadikan seseorang menjadi dirinya sendiri yang tumbuh sejalan dengan bakat, watak, kemampuan, dan hati nuraninya secara utuh. Sedangkan Pembelajaran merupakan suatu proses interaksi antara guru dan siswa beserta unsur-unsur yang ada didalamnya. Unsur-unsur pembelajaran antara lain yaitu kompetensi guru, tujuan pembelajaran, materi pelajaran, sarana prasarana, situasi atau kondisi belajar, media pembelajaran, lingkungan belajar dan model pembelajaran. Semua unsur-unsur tersebut sangat mempengaruhi keberhasilan proses belajar mengajar. 
Proses belajar mengajar merupakan serangkaian perbuatan guru dan siswa atas dasar hubungan timbal balik yang berlangsung dalam situasi edukatif untuk mencapai tujuan tertentu. Guru merupakan salah satu unsur dalam proses belajar mengajar yang harus memiliki kemampuan dalam merencanakan dan melaksanakan proses belajar mengajar dikelas. Seperti yang dikemukakan oleh Santyasa (2007), seorang guru adalah sebagai pelayan kemanusiaan harus mampu memiliki suatu ketrampilan dalam mengajar, yaitu ketrampilan dalam mengembangkan sikap ingin tahu siswa melalui pembelajaran yang beragam sehingga berkreasi dan berpikir kritis. Oleh karena itu, guru dituntut untuk memiliki jiwa kepedualian terhadap anak didiknya sehingga mampu membangkitkan dan mengembangkan aktivitas belajar siswa.

Aktivitas belajar siswa merupakan hal yang sangat penting yang harus dikembangkan (Darmuki dan Hariyadi, 2019). Arikunto, (2005) menyatakan bahwa aktivitas siswa merupakan keterlibatan peserta didik dalam bentuk sikap, pikiran, perhatian, dan aktivitas dalam kegiatan proses pembelajaran guna menunjang keberhasilan proses pembelajaran. Menurut Mulyana (2009:23), Melalui kegiatan pembelajaran semua siswa diharapkan memperoleh pengalaman langsung melalui pengalaman indrawi yang memungkinkan mereka memperolah informasi dari melihat, mendengar, meraba/menjamah, mencicipi, dan mencium. Dari pendapat Mulyana tersebut, dapat disimpulkan bahwa dalam pelaksanaan kegiatan belajar mengajar yang diterapkan oleh guru, siswa dituntut untuk memperoleh pengalaman dan memiliki perubahan-perubahan tingkah laku dalam melakukan pembelajaran. Namun pada kenyataannya, kegiatan pembelajaran disekolah masih banyak kendalakendala yang dihadapi dalam melaksanakan proses belajar mengajar yang aktif melibatkan guru dan siswa.

Berdasarkan hasil wawancara peneliti dengan Bu Yayi Nigsih, S.Pd sebagai guru mata pelajaran IPS kelas VII SMPN 1 Senori, pada hari Senin tanggal 02 Maret 2020 pukul 09.00 WIB (pedoman wawancara terlampir pada lampiran 1 untuk menggali masalah-masalah yang dihadapi guru dalam pembelajaran IPS) diperoleh data tentang kendala-kendala pembelajaran antara lain: 1) sebagian siswa tidak merespon dan mendengarkan penjelasan dari guru, 2) Keaktifan dalam mengerjakan soal-soal latihan pada proses pembelajaran masih kurang karena bergantung pada teman, 3)kemampuan atau ketrampilan siswa bertanya masih rendah begitu pula saat guru mengajukan pertanyaan, tidak banyak siswa yang mampu dan percaya diri untuk menjawab. Akibatnya, suasana kelas menjadi tidak hidup karena kurangnya interaksi antara guru dengan siswa, dan siswa dengan siswa, 4) Partisipasi siswa dalam proses pembelajaran dikelas belum merata, hanya siswa tertentu yang berpartisipasi.

Dari hasil wawancara tersebut terlihat bahwa ada masalah dimana aktivitas dan hasil belajar IPS belum optimal. Hal ini diduga yang menyebabkan kemampuan siswa dalam memahami pelajaran IPS masih rendah dan hasil belajar siswa kurang maksimum. Hal tersebut diperkuat dari data rata-rata nilai akhir IPS siswa kelas VII SMPN 1 Senori adalah dibawah 75, dari 34 siswa hanya 10 anak yang tuntas belajar dan 24 anak tidak tuntas belajar (Sumber : daftar nilai siswa kelas VII pada semester ganjil, tahun 2019 terlampir pada lampiran 4), padahal kriteria ketuntasan minimal (KKM) siswa adalah $\geq$ 75.

Untuk mengetahui permasalahan tersebut, maka perlu adanya pembaharuan dalam penggunaan model pembelajaran yang terletak pada tanggung jawab seorang guru. Dalam 
proses pembelajaran tidak hanya guru yang dituntut untuk berperan aktif, melainkan siswa juga dituntut untuk ikut serta memperlancar model yang diterapkan oleh guru. Oleh karena itu, siswa diharapkan mampu : 1) merespon dan mendengarkan penjelasan dari guru, 2) mengerjakan soal latihan secara kelompok, 3) mengajukan pertanyaan apabila ada materi yang belum dipahami, 4) berpartisipasi dalam proses pembelajaran. Salah satu model pembelajaran yang dipandang sesuai untuk mengatasi masalah sebagaimana diuraikan di atas adalah dengan menerapkan model pembelajaran kooperative tipe group investigation.

Berdasarkan latar belakang di atas, peneliti tertarik untuk mengadakan penelitian tentang "Penerapan Model Pembelajaran Group Invertigation Untuk Meningkatkan Aktivitas dan Hasil Belajar IPS Siswa Kelas VII SMPN 1 Senori”.

\section{Metode}

Penelitian tindakan kelas akan dilakukan dengan gambaran sebagai berikut:

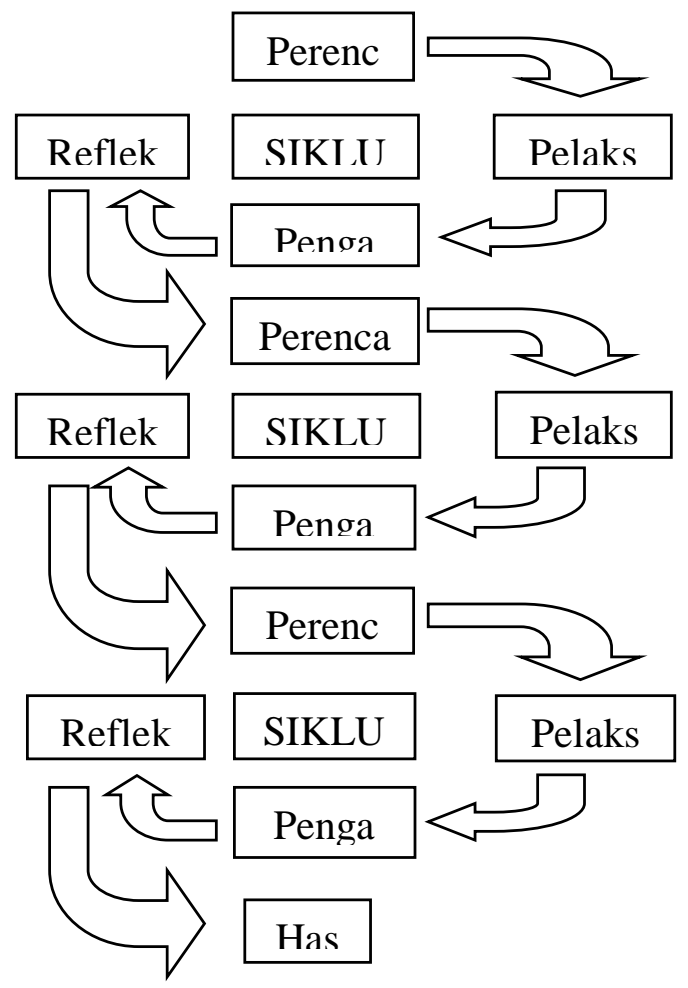

\section{Gambar 3.1 Siklus Penelitian Tindakan Kelas}

(Arikunto, 2011: 16)

Dalam melaksanakan penelitian tindakan kelas terdiri dari empat tahap, yaitu:

1. Perencanaan tindakan (planning)

2. Pelaksanaan tindakan (Action)

3. pengamatan (observation)

4. Refleksi (reflection) 


\section{Hasil dan Pembahasan}

Penelitian yang berjudul "Penerapan Model Pembelajaran Kooperatif Group Investigation Untuk Meningkatkan Aktivitas dan Hasil Belajar Siswa Pada Pelajaran IPS Kelas VII SMPN 1 Senori Tahun Pelajaran 2019/2020", dilakukan untuk membantu guru dalam menangani siswa yang mempunyai masalah terhadap hasil belajar yang disebabkan karena kurang komunikasi mereka dalam belajar. Komunikasi ini dapat ditumbuhkan dengan cara memancing siswa agar mau aktif sharing dalam menjawab maupun bertanya selama proses pembelajaran berlangsung sehingga siswa merasa berperan dalam kelas dan Hasil dari penelitian ini meliputi hal-hal sebagai berikut :

1. Aktivitas Guru Dalam Mengelola Pembelajaran IPS Menggunakan Model Pembelajaran Group Investigation

Aktivitas guru dalam mengelola pembelajaran menggunakan model pembelajaran Group Investigation mengalami peningkatan tiap siklusnya. Untuk dapat melihat peningkatan yang terjadi pada aktivitas guru disajikan dalam tabel 4.17 Sebagai berikut:

tidak hanya mendengarkan saja.

\begin{tabular}{|c|c|c|c|}
\hline No. & Siklus & Presentase Aktivitas Guru \% & Keterangan \\
\hline 1. & Siklus I & $45 \%$ & Kurang Baik \\
\hline 2. & Siklus II & $70 \%$ & Baik \\
\hline 3. & Siklus III & $81 \%$ & Sangat $\mathrm{Br}$ \\
\hline
\end{tabular}

Terlihat bahwa aktivitas guru dalam mengelola pembelajaran ekonomi menggunakan model pembelajaran Group Investigation mengalami peningkatan pada tiap siklusnya.

2. Aktivitas Belajar Siswa Selama Pembelajaran Ekonomi Menggunakan Model Pembelajaran Group Investigation

Aktivitas belajar siswa dalam penelitian ini juga mengalami peningkatan tiap siklusnya. Hasil pengamatan aktivitas siswa disajikan dalam tabel 4.18 Sebagai berikut:

Tabel 4.18 Pengamatan Aktivitas Belajar Siswa Siklus I, II, dan III

$\begin{array}{cccc}\text { No. } & \text { Siklus } & \text { Presentase Aktivitas Siswa\% } & \text { Keterangan } \\ \text { 1. } & \text { Siklus I } & 44 \% & \text { Kurang Baik } \\ \text { 2. } & \text { Siklus II } & 52 \% & \text { Baik } \\ \text { 3. } & \text { Siklus III } & 68 \% & \text { Sangat Baik }\end{array}$

Dapat disimpulkan bahwa aktivitas belajar siswa dalam pembelajaran IPS menggunakan model pembelajaran Group Investigation mengalami peningkatan tiap siklusnya.

3. Hasil Belajar Siswa

Hasil belajar siswa berupa nilai post-tes juga selalu mengalami peningkatan. Kemudian hasil post-tes dari masing-masing siklus kurang mengalami peningkatan pada siklus kedua, namun pada siklus ketiga mengalami peningkatan yang cukup baik. Hasil belajar siswa berupa post-tes dari masing-masing siklus disajikan dalam tabel 4.19 Sebagai berikut: 
Tabel 4.19 Hasil Belajar Siswa Siklus I, II, dan III

$\begin{array}{cccc}\text { No. } & \text { Siklus } & \text { Presentase Hasil Belajar Siswa } \% & \text { Keterangan } \\ \text { 1. } & \text { Siklus I } & 62,83 \% \text { dan } 72,90 \% & \text { Cukup Baik } \\ \text { 2. } & \text { Siklus II } & 71,22 \% \text { dan } 75,96 \% & \text { Baik } \\ \text { 3. } & \text { Siklus III } & 72 \% \text { dan } 78,06 \% & \text { Sangat Baik }\end{array}$

Dari tabel tersebut diketahui bahwa peningkatan yang terjadi antara siklus I dan siklus II belum begitu memuaskan tetapi pada siklus III telah mengalami peningkatan yang cukup memuaskan. Dengan demikian hasil belajar siswa menggunakan model pembelajaran Group Investigation pada materi pelajaran uang Akitivitas manusia dalam memenuhi kebutuhan dikatakan tuntas dengan pencapaian yang sangat baik

\section{Ucapan Terimakasih}

Terima kasih kepada Allah SWT yang telah memberika nikmat kesehatan, Terimakasih untuk semua pihak yang bersangkutan dalam pembuatan jurnal ini, da semua pihak yang terlibat dalam penelitian ini, terutama utuk SMPN 1 Senori yag ntelah memberi izin utul peneliti melakukan penelitia di sana, terimakasih juga untuk kedua orag tua saya yang telah memberi dukungan dan mostivasi, untuk semua pihak yag tidak dapat saya sebutka satu persatu. dan terimakasih untuk dosen pembimbing bapak Dr.Hariyadi, M. Pd Atas segala dedikasi yang diberikan semoga semua ini bermanfaat .

\section{Daftar Pustaka}

Arifin, Zainal. 2010. Metodologi Penelitian Pendidikan Filosofi, Teori \& Aplikasi. Surabaya : Lentera Cendekia.

Arifin, Zaenal. 2013. Evaluasi Pembelajaran (Prinsip Teknik Prosedur). Bandung : PT Remaja Rosdakarya.

Arikunto, Suharsimi., Suhardjono., Supardi. 2011.. Belajar Dan Pembelajaran. Bandung : Alfabeta.

Hamiyah, Nur. dan Jauhar, Muhamad. 2014. Strategi Belajar Mengajar. Jakarta : Prestasi Pustakaraya.

Darmuki, A., Hariyadi, Ahmad, 2019. Peningkatan Minat Dan Hasil Belajar Keterampilan Bebrbicara Menggunakan Mind Map Pada Mahasiswa kelas IA PBSI IKIP PGRI BOJONEGORO TAHUN AKADEMIK 2019/2020. Di Unduh http://jurnal.umk.aci.id/index.php/kredo/index pada tanggal 02 April 2020.

Huda, Miftahul. 2013. Model-Model Pengajaran Dan Pembelajaran. Yogyakarta : Pustaka Belajar.

Iskandar. 2009. Penelitian Tindakan Kelas. Jakarta : Gaung Persada (GP) Press.

Purwanto, Ngalim. 2010. Prinsip-Prinsip Dan Teknik Evaluasi Pengajaran. Bandung : PT Remaja Rosdakarya.

Sudjana, Nana. 2011. Penilaian Hasil Proses Belajar Mengajar. Bandung : PT Remaja Rosdakarya.

Sugianto, Dwi. 2010. Belajar Dan Pembelajaran I. Tuban .

Suprijono, Agus. 2012. Cooperative Learning (Teori \& Aplikasi Paikem). Yogyakarta : Pustaka Belajar

Tim Pengembangan MKPD. 2011. Kurikulum Dan Pembelajaran. Jakarta : PT Rajagrafindo Persada. 


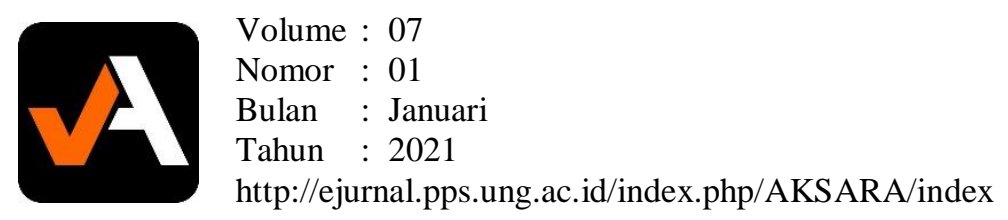

Sriyono. 2010. Aktivitas Belajar. http://www.academia.edu/4570365/Aktivitas-Belajar., di akses 03 April

http://www.academia.edu/4570365/Model pembelajaran Group Investigation. http://www..edu/45670365/ belajar dan aktivitas belajar. 